\title{
Improving lip aesthetics in the face profile after treatment of class II, division 2 malocclusion
}

\author{
KONIAROVA Zuzana ${ }^{1}$, HUSAROVA Romana ${ }^{2}$, STEFKOVA Marie ${ }^{1}$, SPIDLEN Milos ${ }^{1}$, \\ STATELOVA Dagmar ${ }^{3}$, JANICKOVA Maria ${ }^{3}$, KONIAROVA Alena ${ }^{3}$
}

\author{
Department of Orthodontics, Clinic of Dental Medicine, Medical Faculty of Palacky University \\ in Olomouc, Czech Republic. zuzanakoniarova1@gmail.com
}

\begin{abstract}
AIM: The aims of our research were as follows: 1) Description of changes in the position of the upper and lower lips, as a result of the change in the position of upper and lower incisors after orthodontic treatment of malocclusion of Class II, division 2 type. 2) Determination of correlation between changes in the position of lips and incisors in the profile of the face after orthodontic treatment of malocclusion of Class II, division 2 type. MATERIALS AND METHODS: Our study analyses the documentation of 115 patients with malocclusion of Class II, division 2 type treated with a fixed orthodontic appliance in the upper and lower dental arches at the Orthodontic Department of the Clinic of Dentistry in Olomouc from January 1, 1996 to December 31, 2017. There were 78 women and 37 men aged 11 to 36 years included in the database. Cephalometric images of patients from the group taken before and after the treatment were used for the purpose of cephalometric analysis according to Kamínek (1) and Burstone‘s analysis (2) of soft tissues. Subsequently, all output data were processed statistically.

RESULTS: While the protrusion of the incisors after treatment of malocclusion of Class II, division 2 type was $3 \mathrm{~mm}$, the facial profile showed statistically significant changes in soft tissues in the ventral direction by $1 \mathrm{~mm}$ on average just in the area of the upper and lower lips, which means a shift corresponding to one third of teeth movement.

CONCLUSION: A statistically significant change in the position of incisors, soft tissues as well as correlation between changes in hard and soft tissues in the face profile after orthodontic treatment of malocclusion of Class II, division 2 type were demonstrated. The more the incisors were inclined, the more the lips moved forward, and the patient's profile turned out to be aesthetically improved (Tab. 2, Fig. 3, Ref. 39). Text in PDF www.elis.sk

KEY WORDS: class II, division 2 malocclusion, dental movements, soft tissue changes.
\end{abstract}

\section{Introduction}

Although physical attractiveness and perfect aesthetics of the face have always been a concern of interest for experts over the centuries, it has not been clearly defined until present times (3). In general, there is no geometric rule for facial aesthetics. Much more important is the overall harmony of the face (1). Despite the considerable subjective assessment of facial appearance in different individuals, certain rules can be found out in the literature that may serve as approximate guidelines that clinicians follow in trying to

${ }^{1}$ Department of Orthodontics, Clinic of Dental Medicine, Medical Faculty of Palacky University in Olomouc, Czech Republic, ${ }^{2}$ Orthodontic pratcice ORTHODONCIAPH, s.r.o., and ${ }^{3}$ Department of Stomatology and Maxillofacial Surgery, Jessenius Faculty of Medicine in Martin, Comenius University in Bratislava, Slovakia

Address for correspondence: A. Koniarova, MD, PhD, Department of Stomatology and Maxillofacial Surgery, Jessenius Faculty of Medicine in Martin, Comenius University in Bratislava, Kollarova 2, SK-036 01 Martin, Slovakia

Phone: +421903 665336 achieve the desired aesthetic result (4). The use of the so-called golden proportion, described by Dr. Stephen R. Marquardt through his "golden phi mask" is considered significant. The basis of the golden ratio is a special number phi approximately equal to 1.618 (5).

The face profile can be measured using a number of parameters. The angle of facial convexity is a parameter that assesses the relationship between the upper, middle and lower thirds of the face and is formed by the lines G (glabella) - Sn (subnasale) and Sn (subnasale) - Pog (skin pogonion). The average values of this angle range from 164 to $172^{\circ}$. Lower values of this angle indicate a convex facial profile whereas higher values indicate a concave facial profile (6).

In practice, we are most interested in the position of the lips in the profile of the face, which we can influence, most of all, by orthodontic treatment. We evaluate this position according to Ricketts' aesthetic line which is drawn from the tip of the nose to the tip of the chin. The average position of the upper lip is $4 \mathrm{~mm}$ behind this line, the lower lip is $2 \mathrm{~mm}$ behind the line (6).

For patients with Class II, division 2 malocclusion, a concave facial profile, short lower third of the face, protruding chin and 


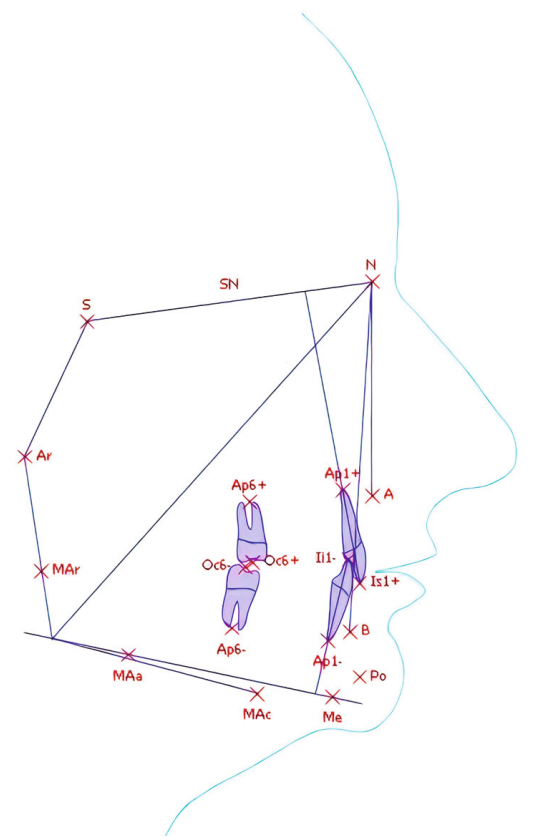

Fig. 1. Cephalometric analysis /borrowed from the author's database/ (source: Database of the Orthodontic Department of the Clinic of Dentistry, Palacky University).

deep mentolabial sulcus are typical $(7,8,9)$. The skeletal basis of the anomaly is a significant anterior growth rotation $(10,11,12)$.

Treatment of Class II, division 2 malocclusion depends on the age of the patient. The treatment aims at achieving a functional and aesthetically satisfactory result with a guarantee of long-term stability (13). However, such a result can only be achieved after a detailed treatment plan is drawn up and agreed to by the patient.

Interceptive treatment during the period of mixed dentition aims to eliminate factors that negatively affect the growth and development of the face. These include retrusion of upper incisors, which can cause retrusion of lower incisors and thus may cause crowding in the lower dental arch.

The correction treatment in permanent dentition leads to definitive correction and improvement of the anomaly. It includes sagittal expansion in the upper dental arch and improvement of the torsion of incisors. The need to perform the sagittal expansion in the lower dental arch, even at the expense of stability, is often associated with the effort to achieve facial aesthetics and optimal occlusal outcome (13). However, long-term therapeutic retention of the result is necessary. Extractions in the lower dental arch are not recommended. Only extreme crowding requires extraction in the upper arch, preferably that of the second premolars. A change in the position of the teeth during orthodontic treatment causes the change in the position of soft tissues (14). Specifically, the position of the lips depends on the position of the incisors in the profile of the face. This change is more significant in patients with thinner lips (1). A change in the facial appearance in patients with malocclusion of Class II, division 2 type is undisputable and is often the main reason to visit an orthodontist (14).

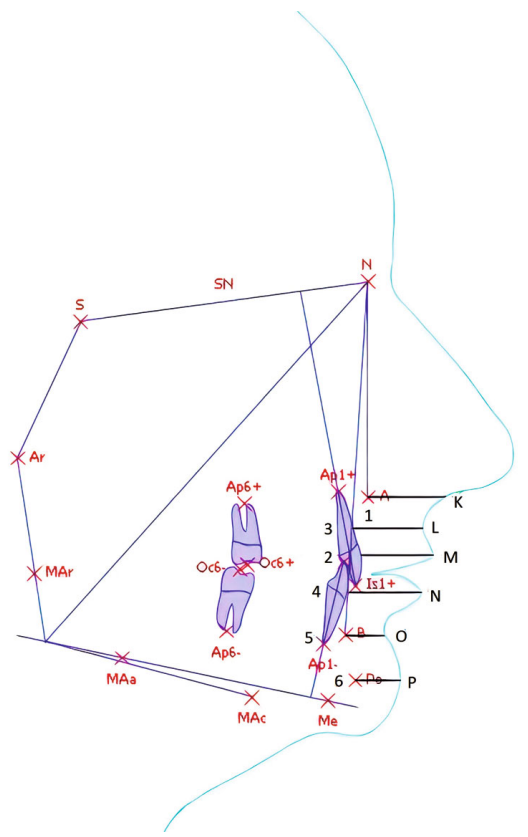

Fig. 2. The Burstone's analysis /the author's own designation/ (source: Database of the Orthodontic Department of the Clinic of Dentistry, Palacky University).

\section{Materials and methods}

Our study analyses the documentation of 115 patients with malocclusion of Class II, division 2 type treated with a fixed orthopedic appliance in the upper and lower dental arches at the Orthodontic Department of the Clinic of Dentistry in Olomouc from January 1, 1996 to December 31, 2017. There were 78 women and 37 men aged 11 to 36 years included in the database.

Due to the different planning of sagittal expansion in the lower dental arch, we were interested in how much the upper and lower incisors protrude in patients with malocclusion of Class II, division 2 type. Due to the significant changes in the position of the lower incisors after the orthodontic treatment, we also decided to examine how the position of lips and soft tissues in the face profile changes after the treatment as well as to assess the correlation between post-treatment changes of soft and hard dental tissues in the ventral direction. The cephalometric images of patients from the group taken before and after treatment were analysed and changes in individual parameters were compared. The following cephalometric values were used for the purposes of this study: angle 1+NS, angle 1-ML, interincisal angle $1+1$, position $1+\mathrm{NPo}$, and position 1-Apo (Fig. 1). They are described as follows:

$-1+1$ value determines the interincisal angle, which indicates the relationship between the upper and lower incisors. Mean values range from $127^{\circ} \pm 8.5$.

- 1-MLvalue; this is the angle formed between the longitudinal axis of the lower incisor and the mandibular line. This line passes through the gnathion and gonion points. The mean value is $94^{\circ} \pm 7$. 
Tab. 1. Values of the cephalometric analysis - change in the position of incisors.

\begin{tabular}{|c|c|c|c|c|c|c|c|c|c|c|}
\hline & \multicolumn{2}{|c|}{$1+1$} & \multicolumn{2}{|c|}{ 1-ML } & \multicolumn{2}{|c|}{ 1-APo } & \multicolumn{2}{|c|}{$1+\mathrm{NS}$} & \multicolumn{2}{|c|}{$1+\mathrm{NPo}$} \\
\hline & before & after & before & after & before & after & before & after & before & after \\
\hline Mean & 143.88 & 130.6 & 93.5 & 101.37 & -1.67 & 1.31 & 91.18 & 99.44 & 2.94 & 4.87 \\
\hline Standard deviation & 22.02 & 13.49 & 7.8 & 9 & 2.9 & 3.1 & 10.02 & 9.02 & 3.75 & 3.51 \\
\hline Population mean & \multicolumn{2}{|c|}{$127 \pm 8.5$} & \multicolumn{2}{|c|}{$94 \pm 7$} & \multicolumn{2}{|c|}{$3 \pm 2$} & \multicolumn{2}{|c|}{$104 \pm 6.5$} & \multicolumn{2}{|c|}{$7 \pm 2.5$} \\
\hline Difference & \multicolumn{2}{|c|}{$13.28^{\circ}$} & \multicolumn{2}{|c|}{$7.87^{\circ}$} & \multicolumn{2}{|c|}{$2.9 \mathrm{~mm}$} & \multicolumn{2}{|c|}{$8.26^{\circ}$} & \multicolumn{2}{|c|}{$1.93 \mathrm{~mm}$} \\
\hline Paired p-test & \multicolumn{2}{|c|}{$<0.05$} & \multicolumn{2}{|c|}{$<0.05$} & \multicolumn{2}{|c|}{$<0.05$} & \multicolumn{2}{|c|}{$<0.05$} & \multicolumn{2}{|c|}{$<0.05$} \\
\hline
\end{tabular}

Tab. 2. Values of Burstone's soft tissues analysis.

\begin{tabular}{|c|c|c|c|c|c|c|c|c|c|c|c|c|}
\hline & \multicolumn{2}{|c|}{$1 \mathrm{~K}$} & \multicolumn{2}{|c|}{$3 \mathrm{~L}$} & \multicolumn{2}{|c|}{$2 \mathrm{M}$} & \multicolumn{2}{|c|}{$4 \mathrm{~N}$} & \multicolumn{2}{|c|}{50} & \multicolumn{2}{|c|}{$6 \mathrm{P}$} \\
\hline & before & after & before & after & before & after & before & after & before & after & before & after \\
\hline Mean & 18.07 & 18.20 & 15.82 & 16.93 & 14.39 & 14.79 & 15.05 & 14.37 & 10.67 & 11.74 & 11.62 & 11.79 \\
\hline Standard deviation & 3.42 & 3.50 & 3.31 & 3.59 & 3.15 & 3.64 & 2.80 & 2.44 & 1.94 & 2.12 & 2.32 & 2.38 \\
\hline Difference & \multicolumn{2}{|c|}{0.13} & \multicolumn{2}{|c|}{1.11} & \multicolumn{2}{|c|}{0.40} & \multicolumn{2}{|c|}{0.68} & \multicolumn{2}{|c|}{1.07} & \multicolumn{2}{|c|}{0.17} \\
\hline Paired p-test & \multicolumn{2}{|c|}{$\mathrm{p}>0.05$} & \multicolumn{2}{|c|}{$\mathrm{p}<0.05$} & \multicolumn{2}{|c|}{$\mathrm{p}>0.05$} & \multicolumn{2}{|c|}{$\mathrm{p}<0.05$} & \multicolumn{2}{|c|}{$\mathrm{p}<0.05$} & \multicolumn{2}{|c|}{$\mathrm{p}>0.05$} \\
\hline
\end{tabular}

- 1-Apo;point A value is the deepest point of the alveolus of the upper jaw in the sagittal plane; corresponds to the anthropological point of the subspinale. Pogonion is the foremost point of the chin in the sagittal plane. Their distance is usually $3 \mathrm{~mm} \pm 2$.

$-1+\mathrm{NS}$ value; this is the angle formed between the longitudinal axis of the upper incisor and the NS line, which is defined by the nasion point and center of sella turcica. Mean values are $104^{\circ} \pm 6.5$.

- 1+NPo value; a position of upper incisors defined by the distance of the cutting edge to the NPo line (nasion point to pogonion point). The mean value should be $7 \mathrm{~mm} \pm 2.5$.

Subsequently, the same cephalometric images taken before and after treatment were subjected to Burstone's analysis (2) of soft tissues. Statistical evaluation was performed by paired t-test and correlation method at the Institute of Medical Biophysics of the Faculty of Medicine of the Palacký University in Olomouc.

According to Burstone's analysis (2) of soft tissues, we constructed the points on cephalometric images. Owing to consistent terminology of points, we marked the points as follows (Fig. 2):

- Point 1; the most posterior point on the anterior contour of the upper alveolar ridge, located about $2 \mathrm{~mm}$ in front of the apexes of the upper incisors

- Point 2; the most anterior point on the vestibular surface of the upper incisor

- Point 3; the most anterior point on the vestibular surface of the upper middle incisor (according to Burstone, point B)

- Point 4; the most anterior point on the vestibular surface of the lower middle incisor

- Point 5; the most posterior point on the alveolus of the jaw in the sagittal plane

- Point 6; the most anterior point on the symphysis of the mandible

- Point K; the point at which the nasal septum between the nostrils merges with the upper cutaneous edge of the midline (according to Burstone, A point)

- Point L; the point located at the site of the greatest concavity of the upper lip (according to Burstone, point B)
- Point M; the most anterior point on the front edge of the upper lip (according to Burstone, point C)

- Point N; the most anterior point on the front edge of the lower lip (according to Burstone, point D)

- Point $\mathrm{O}$; the point located at the site of the greatest concavity of the lower lip (according to Burstone, point E)

- Point P; the lowest point on the contour of the jaw (according to Burstone, point F)

\section{Results}

1. The measurements after the orthodontic treatment showed significant changes in the position and inclination of the upper and lower incisors in patients with malocclusion of Class II, division 2 type. Both incisors were protruded, thus reducing the interincisal angle by $13.28^{\circ}$ and consequently altering also the position of the lower incisor $1-$ APo by $2.9 \mathrm{~mm}$. The position of the upper incisor $1+$ NPo changed by $1.93 \mathrm{~mm}$. The angle $1-\mathrm{ML}$ increased by $7.87^{\circ}$ and the angle $1+\mathrm{NS}$ by $8.26^{\circ}$ (Tab. 1).

2. In terms of soft tissues, the position of the upper lip changed by $1.11 \mathrm{~mm}$ and that of the lower lip by $0.68 \mathrm{~mm}$ in the ventral direction. The most posterior point on the mentolabial groove moved forward by $1.07 \mathrm{~mm}$ (Tab. 2).

3. The results of correlation were statistically proven depending on the shift of soft and hard dental tissues in terms of protrusion as follows:

- minus 0.26 (correlation of the upper incisor and the upper lip)

- minus 0.2 (correlation of the lower incisor and the upper lip due to both protrusion and intrusion of incisors) (Fig. 3).

\section{Discussion}

The aim of our study was to determine changes in the position of incisors, lips and soft tissues in face profiles in patients with Class II, division 2 malocclusion as well as to assess their correlation after the orthodontic treatment. 

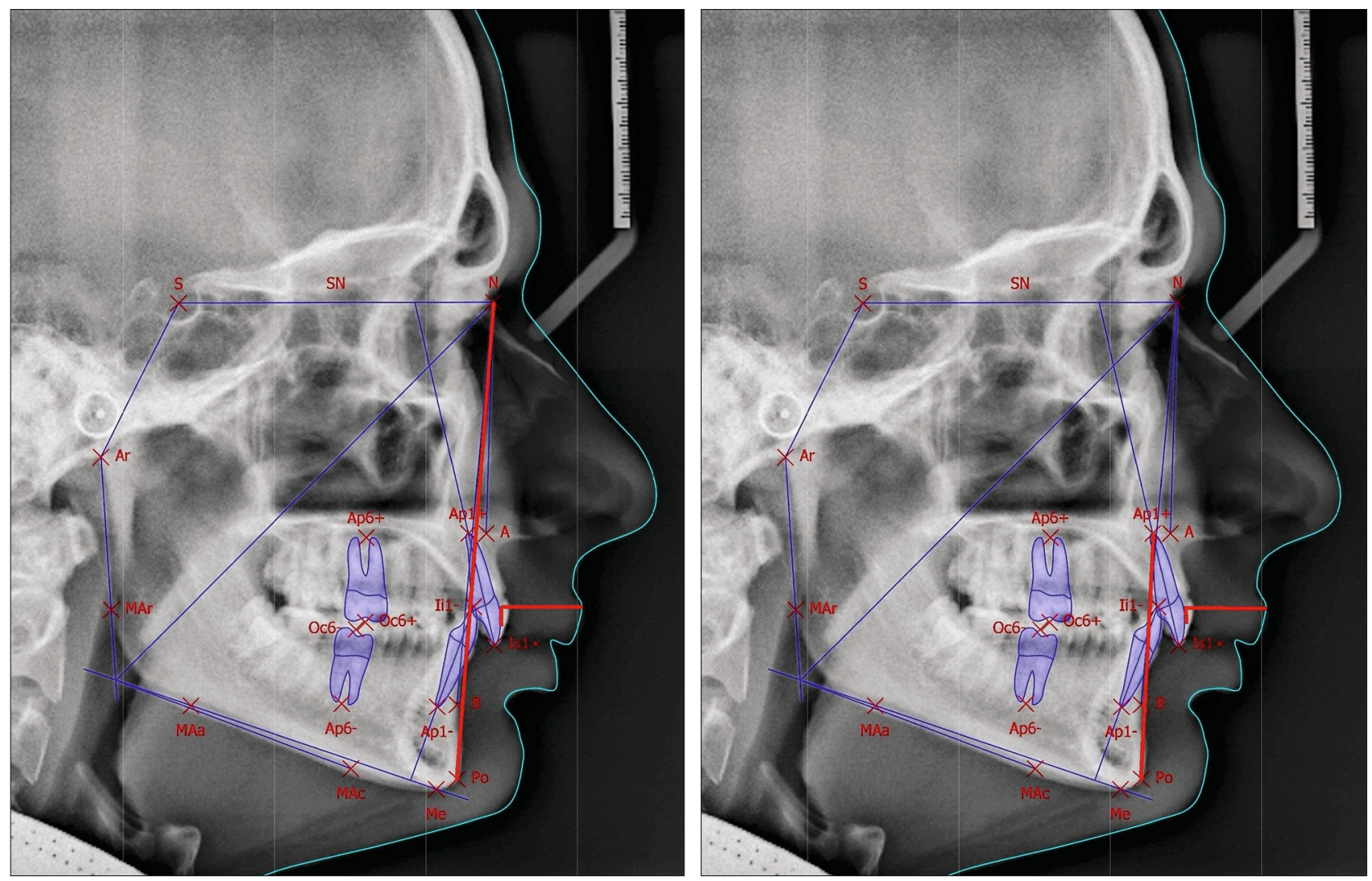

Fig. 3. Correlation of the upper (on the left) and lower (on the right) incisors to the upper lip /the author's own clinical material/ (source: Database of the Orthodontic Department of the Clinic of Dentistry, Palacky University).

In a group of 115 patients aged 11 to 36 , with Class II, division 2 malocclusion treated with non-extraction therapy using a fixed orthodontic appliance in the upper and lower dental arches, the upper and lower incisors were protruded, thus reducing the interincisal angle by $13.28^{\circ}$, from the average value of $143.88^{\circ}$ to that of $130.6^{\circ}$. To achieve occlusal stability, Downs (15) prefers the interincisal angle of 135.4. Steiner (16) states an angle of 131. The position of the lower incisor to the APo line changed by $2.9 \mathrm{~mm}$ from the average value of $-1.67 \mathrm{~mm}$ to that of $1.31 \mathrm{~mm}$, and the position of the upper incisor to the NPo line changed by $1.93 \mathrm{~mm}$ from the average value of $2.94 \mathrm{~mm}$ to that of $4.87 \mathrm{~mm}$. This shift of the front teeth was also associated with the shift of soft tissues of the lower and upper lips in the ventral direction. After the treatment, the upper lip moved by $1.1 \mathrm{~mm}$ on average from the average value of $15.82 \mathrm{~mm}$ to that of $16.93 \mathrm{~mm}$, while the lower lip moved by $0.68 \mathrm{~mm}$ on average from the average value of $15.05 \mathrm{~mm}$ to that of $14.07 \mathrm{~mm}$. From the above facts, it follows that the change in soft tissues corresponds to one third of teeth shift.

There are almost no articles in the literature describing the change in the position of soft tissues in the facial profile during malocclusion of Class II, division type 2 treatment. Most authors $(17,18,19,20,21)$ examine the response of the lips and soft tissues of the face as a result of incisor retraction.
Proffit (22) states that the retraction of upper incisors is followed by a shift of the upper lip by $2 / 3$ of teeth shift. Nanda (23) describes that the position of upper lip is affected by the retraction of upper and lower incisors and rotation of the mandible. While the change in the position of the lower lip was affected by the change in the position of the mandible, the correlation between the position of the lower incisors and retraction of the lower lip were not confirmed.

In his study, Holdaway $(24,25)$ claims that in patients with lip thickness of more than $18 \mathrm{~mm}$, the retraction of the incisors either does not change the position of the lips at all, or only to a minimum. The change in the position of lips is well achieved if the lip thickness is within the normal values of $13-15 \mathrm{~mm}$. With a lip thickness of $12 \mathrm{~mm}$ or less, the change in the position is as fast as the movement of the tooth. Many other authors (26, 27, 28, 29 ) including us in our study, agree with the statement that more significant changes in the profile are more observable in patients with thinner lips regardless whether protrusion or retrusion of incisors is involved. Thicker lips cause less significant after-treatment changes in the profile, but at the same time, can mask, to some extent, the existing deficiency in patients with malocclusion of Class II, division 2 type (28).

Mirabella et al (27) state a change in the position of the upper incisor after protrusion by $3.75 \pm 0.67 \mathrm{~mm}$. When the incisor 
shifts by $1 \mathrm{~mm}$ ventrally, the lips move by $0.10 \mathrm{~mm}$ in the same direction.

According to Kuhn (26), who studied the effect of incisor movement in the sagittal direction on the soft tissue profile, the change in the position of labrale superius by $0.59 \mathrm{~mm}$ can be expected with each millimeter of horizontal movement of the most anterior point on the upper central incisor. Changes in the lip position were less significant in patients with initially thicker lips than in those with thinner lips.

In addition to the initial lip thickness, the size of the interincisal angle before treatment significantly contributes to the final effect of orthodontic treatment in terms of incisors, lips, and soft tissues of the face, which can serve as an indicator of how much the incisors need to be protruded. The larger the initial angle, the more significant the inclination of the incisors and more observable the changes in lip position $(26,27)$.

Fidler (30) and Freitas (31) did not show a statistically significant correlation between hard and soft tissue changes when comparing extraction and non-extraction orthodontic treatments. They suppose that the results of their study are associated with individual morphology and response of soft and hard tissues to treatment.

The ability to accurately predict soft tissue changes after treatment would be very beneficial in orthodontic treatment planning. However, despite the existence of significant correlations between dental movements and soft tissue changes, it is not possible to unambiguously determine the therapeutic outcome in terms of the lips and soft tissues. Patients should be informed about a wide range of possible soft tissue responses caused by orthodontic treatment (26), and it is also necessary to take account of individual view and approach to aesthetic assessment of a facial profile $(32,33,34,35)$.

\section{Conclusion}

We demonstrated statistically significant changes in the position of the upper and lower incisors in terms of both reduction in interincisal angle and their position in the face profile. A significant change in the position of the lips and soft tissues after the end of orthodontic treatment of Class II, division 2 malocclusion was also demonstrated. The protrusion of the incisors was $3 \mathrm{~mm}$ on average and movement of the upper and lower lips was $1 \mathrm{~mm}$ on average. It follows that the change in soft tissues corresponds to one third of the change in the position of teeth. However, the lip thickness is significantly applied. The fuller they are, the less they follow this change. In the case of Class II, division 2 malocclusion, the inclination of the incisors and related movement of lips in the profile significantly contributed to the improvement in the aesthetic appearance of the face.

In general, it can be stated that by changing the position of incisors, we also change the position of lips. However, changes in the position of the chin and nose cannot be achieved just with the orthodontic treatment $(36,37)$. The results of the correlation were statistically demonstrated in relation to the shift of soft and hard dental tissues in the ventral direction. Due to both unstable position of the incisors after treatment and genetic basis of the anomaly, the need for long-term retention of the treatment result is necessary.
Nowadays, a gradually stronger emphasis is being placed on facial aesthetics (38). The role of soft tissues in the profile of the face is not negligible and its importance should not be forgotten in creating a treatment plan (39).

\section{References}

1. Kamínek M et al. Ortodoncie. Praha: Galén 2014. pp. 42, 55, 56.

2. Burstone CJ. The integumental profile. Am J Orthod 1958; 44: 1-24.

3. Dohnalová M, Marek I. Perception of facial profile attractiveness. Ortodoncie 2016; 25 (2): 75-86.

4. Edler R, Agarwal P, Wertheim D. The use of anthropometric proportion indices in the measurement of facial attractiveness. Eur J Orthodont 2006; 28 (3): 274-281.

5. Thurzo A et al. Moderná diagnostika, simulácie a 3D tlač v zubnom lekárstve. Bratislava: Univerzita Komenského v Bratislave 2021, 55 p.

6. Dohnalová M. Vnímání atraktivity obličeje. Odborná práce ke specializační zkoušce z oboru ortodoncie, Olomouc 2014.

7. Peck S, Peck L, Kataja M. Class II Division malocclusion: a heritable pattern of small teeth in well-developed jaws. Angle Orthod 1998; 68 (1): 9-20.

8. Burstone ChJ, Van Steenbergen E, Hanley KJ. Modern edgewise mechanics and the segmented arch technique. Department of Orthodontics, University of Connecticut, School of Dental Medicine, Farmington, Connecticut 1995 .

9. Bell WH. Correction of the short-face syndrom-vertical maxillary deficiency: a preliminary report. J Oral Surg 1977; 35 (2): 110-120.

10. Bjork A, Skieller V. Normal and abnormal growth of mandibule. A synthesis of longitudinal cephalometric implant studies over a period of 25 years. Eur J Orthod 1983; 5 (1): 1-46.

11. Sassouni V. Orthodontics in dental practice, St. Louis: Mosby-Year Book 1971.

12. Nemeth RB, Issacson RJ. Vertical anterior relapse. Am J Orthod 1974; 65 (6): 565-585.

13. Koniarová A, Sedlatá Juráskova E, Špidlen M, Statelová D. The influence of orthodontic non-extraction treatment on the change in the inclination and position of incisors in the Europoid race. Bratisl Med J 2017; 118 (11): $662-668$.

14. Utíkalová K. Profil obličeje. Atestační práce ke specializační zkoušce z ortodoncie, Olomouc 2007.

15. Downs WB. Analysis of the Dentofacial Profile. Angle Orthod 1956; 26: $191-212$.

16. Steiner CC. Cephalometrics in Clinical Practice. Angle Orthod 1959; 29: 8-29.

17. Rudee DA. Proportional profile changes concurrent with orthodontic therapy. Am J Orthod 1964; 50 (6): 421-434.

18. Ricketts RM. Esthetics, environment, and the law of lip relation. Am J Orthod 1968; 54 (4): 272-289.

19. Wisth PJ. Soft tissue response to upper incisor retraction in boys. $\mathrm{Br}$ J Orthod 1974; 1 (5): 199-204.

20. Kocadereli I. Changes in soft tissue profile after orthodontic treatment with and without extractions. Am J Orthod Dentofacial Orthop 2002; 122 (1): 67-72. 


\section{5-190}

21. Ramos A, Sakima M, Pinto A, Bowman SJ. Upper lip changes correlated to maxillary incisor retraction - a metalic implantat study. Angle Orthod 2005; 75 (4): 499-505.

22. Proffit, WR, Fields HW. Contemporary orthodontics. St.Louis: Mosby 2000 .

23. Lai J, Ghosh, J, Nanda, RS. Effects of orthodontic therapy on the facial profile in long and short vertical patterns. Am J Orthod Dentofacial Orthop 2000; 118 (5): 505-513.

24. Holdaway RA. A soft-tissue cephalomeric analysis and its use in orthodontic treatment planning. Part I. Am J Orthod 1983; 84 (1): 1-28.

25. Holdaway RA. A soft-tissue cephalomeric analysis and its use in orthodontic treatment planning. Part II. Am J Orthod 1984; 85 (4): 279-293.

26. Kuhn M, Markic G, Doulis I, Göllner P, Patcas R, Hänggi MP. Effect of different incisor movements on the soft tissue profile measured in reference to a rough-surfaced palatal implant. Am J Orthod Dentofacial Orthop 2016; 149 (3): 349-357.

27. Mirabella D, Bacconi S, Gracco A, Lombardo L, Siciliani G. Upper lip changes correlated with maxillary incisor movement in 65 orthodontically treated adult patients. World J Orthod 2008; 9 (4): 337-348.

28. Perović T. The influence of Class II Division 2 Malocclusions on the Harmony of the Human Face Profile. Med Sci Monit 2017; 23: 5589-5598.

29. Oliver BM. The influence of lip thickness and strain on upper lip response to incisor retraction. Am J Orthod 1982; 82 (2): 141-149.

30. Fidler $\mathbf{P}$. Face profile changes during orthodontic treatment with fixed appliances. Ortodoncie 2009; 1: 25-37.

31. Freitas BV, Rodrigues VP, Rodrigues MF, de Melo HVF, dos Santos PCF. Soft tissue facial profile changes after orthodontic tretment with or without tooth extractions in Class I malocclusion patients: A comparative study. J Oral Biol Craniofac Res 2019; 9 (2): 172-176.

32. Ramsay JL, Langlois JH, Hoss RA, Rubenstein AJ, Griffin AM. Origins of a stereotype: categorization of facial attractiveness by 6-monthold infants. Dev Sci 2004; 7 (2): 201-211.

33. Roberts SC et al. Female facial attractivenes increases during the fertile phase of the mestrual cycle. Proceedings of the Royal Society 2004; 271: 270-272.

34. De Bruine LM. Trustworthy but not lust-worthy: context-specific effects of facial resemblance. Proceedings of the Royal Society 2005; 272: 919-922.

35. Yehezkel S, Turley PK. Changes in the African American female profile as depicted in fashion magazines during the 20th century. Am J Orthod Dentofacial Orthop 2004; 125 (4): 407-417.

36. Kusnoto J, Kusnoto $\mathbf{H}$. The effect of anterior tooth retraction on lip position of orthodontically treated adult Indonesian. Am J Orthod Dentofacial Orthop 2001; 120 (3): 304-307.

37. Brock RA, Taylor RW, Buschang PH, Behrents RG. Ethnic differences in upper lip response to incisor retraction. Am J Orthod Dentofacial Orthop 2005; 127 (6): 683-691.

38. Grzywarcz I. The value of the aesthetic component of the Index of Orthodontic Treatment Need in the assessment of subjective orthodontic treatment need. Eur J Orthod 2003; 25 (1): 57-63.

39. Sarver DM. Interactions of hard tissues, soft tissues and growth over time, and their impact on orthodontic diagnosis and treatment planning. Am J Orthod Dentofacial Orthop 2015; 148 (3): 380-386.

Received August 4, 2021. Accepted November 23, 2021. 